\title{
NOG IETS OVER DE ZEVEN SLAPERS.
}

DOOR

H. T. DAMSTÉ.

In mijn Zeven Slapers-artikel in deel 98 dezer Bijdragen citeerde ik uit het Tijdschrift voor het Binnenlandsch Bestuur Juli 1914 de mededeeling van Dr. Ph. S. van Ronkel, dat de Moslims in de Kaukasus en oostelijker landen den naam Katmir van der Slapers hond op hun poststukken bezigden in den zin van ,,aangeteekend”. Door de post-administratie ginds scheen dat zoo te zijn aanvaard.

Ik verzuimde professor van Ronkel te vragen, hoe hij dit had ervaren, van welken zegsman of uit welke bron; maar achteraf mocht ik 't van hem vernemen: 't Staat te lezen in Wilhelm Weyh's „Zur Geschichte der Siebenschläferlegende", Zeitschrift der Deutschen Morgenländischen Gesellschaft, 65ste Band, 289-301.

De door Huber behandelde Europeesche lezingen en Syrische, Koptische, Armeensche, Arabische en Perzische legende-teksten vult Weyh aan met door N. Th. Katanov in Russische tijdschriften gepubliceerde Tataarsche, Kirgizische en Kasan-Tataarsche vertelsels.

Volgens Weyh stammen al die Mongoolsche lezingen uit de AlKisâ' 1 -tekst, maar het gebeuren hebben hun auteurs gelocaliseerd in eigen land: Oost-Turkistan. Dakianus lieten zij er zijn residentie bouwen te Karā-hogā. Voorts hebben zij het stuk geïslamiseerd: Slapers en Dakianus, allen waren zij Mohammedànen!

Zoo ging de religieus-dogmatische strekking van de Christelijke legende verloren; doel werd: lezers of luisteraars te boeien, en de afwijkende architectuur der bouwwerken van Karā-hogā te verklaren : de legende werd tot een sage.

:De Kasan-Tataarsche tekst $T$, volgens Weyh de minste van de vier die hij behandelt, komt méér dan éénige andere met de Atjèhsche teksten overeen in de aanbeveling van het gebruik van der Slapers namen als middel om heil te erlangen en onheil te keeren. In die Atjèhsche schrifturen geschiedt dat in de kōteubah (preek, 
proloog); in tekst T, anno 1766 te Kasan gedrukt en vaak herdrukt met titel Fauz al-nadjāt (vrij vertaald: Hoe redding te erlangen), is de aanprijzing hoofdzaak en wordt het verhaal zelf slechts zeer in het kort verteld. Die aanprijzing in $\mathrm{T}$ resumeert Weyh aldus:

„Der Name eines jeden hat seine besondere Eigenschaft. Wer ihre Namen reinen Herzens ausspricht oder sie nur bei sich trägt, der erhält die Erfüllung seiner Wünsche, bleibt unversehrt, bleibt Sieger; ihm und seinen Eltern werden die Sünden vergeben. Er bleibt von Kummer und Krankheit, von Unglück und Gram verschont. Wer vom Morgen bis zum Abend die Namen bei sich trägt, wird lange und glücklich leben. Wer sie morgens und abends liest, dem vergibt Gott seine Sünden, der versinkt nicht im Wasser und verbrennt nicht im Feuer. Schreibt man die Namen auf ein Stück Papier, steckt dieses in einen Wollfleck und wirft das ganze in ein Feuer, so erlöscht es sofort. Stehen die Namen auf einem Stücke unserer Habe, so raubt es weder Dieb noch Wasser noch Feuer. Schreibt man die Namen auf einen Holzspan und befestigt ihn am Brot, so berührt keine Heuschrecke das Brot. Papier mit den Namen beschrieben und an der linken Seite einer Schwangeren befestigt, erleichtert die Geburt, wie ja überhaupt diese Namen dem Menschen die Erfüllung seiner Wünsche erleichtern; man muss aber nicht nur die Namen der Jünglinge schreiben, sondern auch den Namen des Hundes. Man graviert sie gerne auf Fingerringe, Gürtelschnallen und Siegel”.

Wij zien : de overeenkomst met de tot de Atjèhsche teksten behoorende prologen is treffend; Kasan'sche en Atjèhsche stellers moeten wel uit één bron hebben geput. Bij Huber leest men weinig over de heilzame werking van der Zeven Slapers namen; alleen op p. 709 noemt hij een handschrif te München (Cod. Arab. 195), volgens hetwelk de Siebenschläfer worden aangeroepen ,,beim Suchen, bei Krieg und Brand, beim Weinen der Kinder, zur Fernhaltung von Dieben, von Schiffbruch, von Zorn und Ärger, zur Vermehrung des Verstandes”. Ontmoeten Kasan en Atjèh elkaar te München? 